\title{
Abortion among teenagers in Vietnam today
}

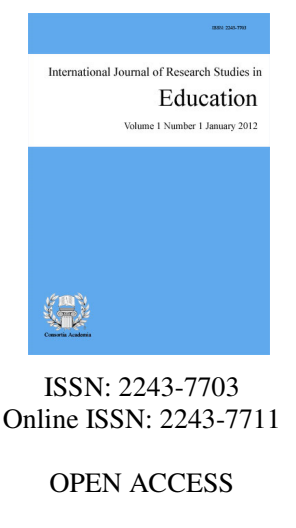

\section{Abstract}

Last decades, the rate of abortion in Vietnam has constantly increased and has been reaching up to an "alarming level," mostly among teenagers. The major reasons that have caused this sad reality are the decreasing of consciousness about the value of human life, especially the conflict between the two existing cultures in Vietnamese society today: the "imported" Western culture in which the movement of "living-in" is considered as "fashionable trend" among the Vietnamese teens, and the traditional Vietnamese culture in which value of traditional marriage is highlighted, particularly, having a baby outside the marriage under any form is still not accepted, even this is a shameful thing for the family. This sad phenomenon has caught great concern from the parents and the educators as well. Being a religious educator, the researcher would like to choose and study deeper about this moral issue: Abortion among teenagers in Vietnam today. By using the theological pastoral method "See, Judge, and Act," this paper will help to understand the Vietnamese context and identify the major elements that cause the moral issue of abortion among Vietnamese teens (See), and then, discerning this issue of abortion from the Biblical, Magisterial and Cultural Perspectives (Judge). Finally, from the pastoral point of view, proposing some practical and appropriate ways that can help in the effort to improve this current moral situation (Act).

Keywords: abortion, human fetus, Vietnamese teenagers, theological pastoral method, Vietnamese context 


\section{Abortion among teenagers in Vietnam today}

\section{Introduction}

In the common trend of globalization, Vietnamese culture has the opportunity to encounter and interact with other cultures all over the world. Therefore, it has gradually interchanged with foreign cultures, especially European and American cultures. Accordingly, in the sexual field, Vietnamese people, especially the young ones nowadays, tend to be liberal in their sexual life. In addition, the policies of family planning of the government have been also drastically imposing on the people for the sake of regulation of population. All of these have created misconceptions about human life, particularly unborn babies. As a result, abortion is widespread throughout the country, from teenagers to married people (Quang Huyen, 2010).

Besides, for the young migrants in the big cities due to their livelihoods or studies, they have to face up to a life away from their hometown, especially away from the supervision of their parents. At the same time, they have to deal with the challenges of "rice, clothes, and money." In such circumstances, they are easily infected with the needs of life enjoyment, living together, particularly the movement of "live-in." Many young people have gone against the traditional values that they have been taught and advised by their parents; many teenagers let go of their sexual life, got unexpectedly pregnant, and then, led to an abortion (Quang Huyen, 2010).

According to a Vietnamese Journalist, Minh Chau, in his writing entitled, "Alert Status of Adolescent Abortion" (Minh Chau, 2021), the recent rate of abortion among adolescents in Viet Nam is the highest among Southeast Asian countries. Besides, Vietnam is also one of the five countries with the highest abortion rate in the world. In fact, at the Central Obstetrics and Gynecology Hospital, the average number of abortions per day is about 40-50 cases, a year is about 5,000 cases, of which about $18-20 \%$ are in teenagers.

Also from this source, according to the Department of Maternal and Child Health (Ministry of Health) in Vietnam, an average of 300 to 400 thousand abortions, aged 15-19 years old, are officially reported each year, of which 60-70\% are students. And, according to the General Department of Population and Family Planning, although the abortion rate in Vietnam has decreased in the past 10 years, the abortion rate among adolescents and young people has shown signs of increasing, accounting for more than $20 \%$ of abortions. In addition, according to the data recorded at the Central Obstetrics and Gynecology Hospital, each year, about 900 cases of teenagers go to the hospital for abortion. There are cases in which 15-year-old girl who have had two times of abortion. But, this is just the floating surface of an iceberg because, it is noted that, in public establishments and private clinics registered for abortions, the proportion of abortion recorded in 2017 is near 30,000 cases. This is a very alarming number!

In addition, as many countries around the world, abortion has been legalizing indirectly in Vietnam in recent years. And this is creating a good condition for public and private places where abortion is carried out. As the result, abortion is done easier and more conveniently. Unconsciously, this is promoting abortion among Vietnamese women, especially young teenagers. All of these are raising a big concern for the parents and educators, particularly the religious educators, including the researcher. And this is the most reason why she would like to study and write about this moral issue: Abortion among teenagers in Vietnam today, with the hope that her local Congregation, and herself, can partly contribute something in the effort to improve this situation.

\section{Methodology}

In this research paper, the researcher would like to use primarily the theological pastoral method, "See, Judge, and Act." In fact, "in terms of research methods, 'See-Judge-Act' could be described as a type of action research... [This method] can be described as a holistic approach geared toward the grasp of truth about reality from a most comprehensive perspective" (Fernando, 2010, p. 5). The "See" part of this research will look at the 
current context of Vietnam where the Vietnamese teenagers are living to understand this context and more importantly, identify what are the major elements that cause the moral issue of abortion among Vietnamese teens to become serious as of now. The "Judge" part of this paper will discern the current moral issue of abortion among Vietnamese Teenagers in the light of Sacred Scripture, Magisterium, and Vietnamese Culture. Finally, based on the correlation between the "See" and "Judge" part of the research is to "Act." Hence, this part will propose or suggest some practical and appropriate ways that, the researcher thinks, are relevant and effective in improving this moral situation of Vietnamese teenagers.

To realize this endeavor, this paper follows underlying frameworks with the theological pastoral method "See, Judge, Act." This method serves as structured guidelines of what should be done step by step. This section is composed of: understanding the Vietnamese context and identify the major elements that can cause the moral issue of abortion among Vietnamese teens (SEE), discerning this issue of abortion from the Biblical, Magisterial and Cultural Perspectives (JUDGE), and from the pastoral point of views, proposing some practical and appropriate ways that can help in the effort to improve the situation relating to the moral issue of abortion.

\section{Discussion}

\subsection{Current Context of Vietnam}

Vietnamese society is changing and developing rapidly in different fields today. For the Vietnamese people, particularly the young ones, there are various challenges and opportunities at the same time. In this part, the current context of Vietnamese society will be presented but only insofar as the context has been seen to affect the moral issue of abortion among Vietnamese teenagers. And from this present context, the researcher will identify major elements that can cause the high rate of abortion among these teens.

Socio-Economic Situation - In the last decades, as in many other developing countries, the phenomenon of globalization has blown a new current into the economy of Vietnam. It is the current of globalization that creates the growing interdependence to each other among countries all over the world, especially in the field of economy (Gao Shangquan, 2000). Faced with this reality, the Vietnamese government chose the policy of "open door" to adapt to the new situation of the world. And in fact, this policy has helped the Vietnamese economy to achieve certain successes in the past. In recent years, especially the Permanent Deputy Prime Minister of Vietnam confirmed that, "Vietnam belongs to the group of economies with the fastest growth rate in the region and the world" (Thai Ba Dung, 2019). As a result, the living condition of Vietnamese people has been greatly improved (Nguyen Van Dan, 2009). In an analysis of the social realities in Vietnam, entitled "Overview of Vietnamese Society during the Renewal Process for Development and International Integration," Pham Xuan Nam (2000), the author of the study concluded that:

With the important achievements and valuable experiences of the country's comprehensive renovation process over the past 20 years, we have reason to believe in Vietnam's bright future in social development and international integration in the coming years... alongside its friends from all over the world striving for peace, national independence, democracy and social progress of all humanity. (p. 9)

And as a response, in the speech on "Update on Vietnam's socio-economic development and prospects" at the $48^{\text {th }}$ Chief Financial Officer World Conference, Nguyen Thien Nhan, Secretary of Ho Chi Minh City Party Committee, stated that, after 32 years of renovation from 1986 - 2017, Vietnam's economy has achieved remarkable achievements and reached the top 50 of the world economies. He added that social development has also made certain progress, such as reducing poverty, covering health insurance, and completing lower secondary education. Notable as well is the freedom of religious belief as affirmed by the Constitution and gender equality have been recognized (Lan Anh, 2018). Such possible developments in Vietnam would be credited to the influence of globalization. Like other societies all over the world, however, we cannot deny that the trend of 
globalization has its negative sides, tremendously affecting the life of the people, especially the youth. Indeed, in a recent interview that was held by the Vatican News, when asked about how the Vietnamese society today has affected the young, Father Thomas Vu Quang Trung (2019) said that:

In the context of Vietnamese society today, everyone sees that the more the country's economy develops, the more ethical and moral life in society goes down. Less good mirror, worse mirror. The school is no longer a safe but violent place. Cramming with much knowledge whereas teaching how to live as a person is not taken seriously. The traditional values in family life are broken. The secularized atmosphere pervades virtual values in social life, making it difficult for young people to determine a basic orientation for their life. (par. 4)

Cultural Situation - In the common trend of globalization, Vietnamese culture has the opportunity to encounter and interact with other cultures all over the world. Therefore, it has gradually interchanged with foreign cultures, especially Western culture that is mainly characterized by materialism and individualism. From the cultural perspective, "Materialism is the attitude of someone who attaches a lot of importance to money and wants to possess a lot of material things" (Collins Dictionary) According to this definition, we can say that materialism has been taking over the life philosophy of many Vietnamese people, especially the young ones (Ha Noi Economic University, 2015). This is because, along with the development in the economic field as mentioned above, the material life of Vietnamese people has improved a lot (Nguyen Van Dan, 2009). But too much dependence on economic progress makes many people value money and other material things more than spiritual and moral values (Nguyen The Long, 2012). As a result, precious traditional values in Vietnamese culture are gradually eroding (Nguyen The Long, 2012).

In most Western countries, it is obvious that individualism is valued and promoted. Accordingly, they underline the importance of the individual's freedom, independence, and happiness over that of the group (Mark A. Ashwill and Thai Ngoc Diep, 2005). Unlike these countries,

Vietnam [is] as a collectivist society in which the group takes precedence over the individual... relationships are key, and harmony is the goal of virtually every activity and interaction...Every person has his place within the family, the village, and the larger society. One's place determines one's duties, responsibilities, and privileges. (Mark A. Ashwill and Thai Ngoc Diep, 2005, pp 79-80)

However, because of globalization, this collective culture is gradually replaced by a culture of individualism that is prominent in Western culture. And this has affected especially the young people who were born and have grown in this era as observed by Friar Guy Lespinay that, "today's young people are very individualistic and little accustomed to living with others. Nuclear families also promote individualism (Guy Lespinay, 2009). In addition, together with the culture of individualism, the movement of "living-in" is becoming a popular and fashionable trend among Vietnamese teenagers nowadays.

On the other side, having a long history of being dominated by China, Vietnamese culture is still strongly influenced by Chinese culture, particularly Confucianism in which the value of traditional marriage is highlighted, especially, having a baby outside the marriage under any form is not accepted, even this is shameful for the family. As a result, if the young girls accidentally get pregnant, they will secretly solve "their problems" in their ways. In fact, in this situation, abortion is the best choice for them: fast and effective right away!

So, what we see here is the tension, conflict between the culture of the young that is strongly influenced by Western culture and Vietnamese traditional culture. And this conflict unconsciously pushed the young girls who have unexpected pregnancies to the act of abortion as an instant solution and remedy for them.

Social-Media Situation - In the age of science and technology as currently, Vietnam, like other countries all over the world, the internet is the media that has been used the most, and social media is becoming the common 
Abortion among teenagers in Vietnam today

form of communication among Vietnamese people, especially the youth (Nguyen Thang, 2019).

According to the 2019 report of Digital Marketing of WeareSocial and Hootsuite (Hoang Lam, 2019), out of the total population of Vietnam (97 million), there are 143.3 million multi-mobile subscriptions, 64 million internet users, 62 million active social media users, and 58 million mobile social media users. In the same survey conducted by this group of WeareSocial and Hootsuite, the time spent for media by Vietnamese is astonishing. For example, the daily average Vietnamese users spend time for internet via any device is 6 hours 42 minutes; social media via any device is 2 hours 32 minutes; for TV viewing, 2 hours 31 minutes; and for listening to streaming music 1 hour 11 minutes. From this statistics, the survey concluded that $94 \%$ are daily Internet users in Vietnam. Only 6\% are internet users at least once a week. Moreover, according to this research, a major difference in this year (2019) compared to the statistics of the past years, YouTube has surpassed Facebook to become the most active social network in Vietnam. Google statistics shows that Vietnam belongs to the top five countries, standing even above developed countries such as Japan, Korea, or Taiwan in the world, watching videos on YouTube. Clearly, from the statistics above, we see that the internet has become a routine activity of the majority of Vietnamese.

Educational Situation - Regarding the educational situation in Vietnam today, the first significant point that the researcher would like to highlight here is the removing the subject of morality in the current curriculum. Indeed, according to the past educational system, there was a subject of ethics with valuable lessons regarding moral life in the curriculum. However, when the Communist Party took over the whole country, this subject gradually disappeared from the curriculum, and it was replaced by the subject of Civic Education that more lean on the political and socialist realm. As a result, over time, ethical values or moral lessons in life are constantly eroded and neglected in today's society up to the point that, in the mind of the young generation nowadays, abortion or killing unborn children is normal for them. Indeed, according to Father Tuong $\mathrm{Cu}$, a member of Vietnamese Missionaries of Asia, in his interview of the cases of abortion. When a young woman was asked: Did you know that abortion is the killing of a human, and this is your baby? She replied: yes, without any regret! On another occasion, he had a chance to discuss with a young facilitator of abortion in Đong Nai Hospital. When this one was asked: "Do you feel uneasy about removing the fetus out of their mother's womb, especially for those fetuses in the stage of four-five weeks? The nurse answered: "Even their mothers do not want them, who am I to think about that! So, after I helped them to abort, they just took a few minutes to rest, and then, went away. They did not even take a look to see their babies. It seemed they had just doffed a debt" (Tuong $\mathrm{Cu}, 2017$ ).

Through those cases, I realized that in the view of those young people, the fetus is not human. So, if they cannot see the value of human beings from the fetus, they will decide to have an abortion easily. Sadly, this reality is signaling the moral decline among Vietnamese teenagers, particularly in the moral issue of abortion. And the removal of the Ethic Subject from the curriculum is the indirect cause of this reality.

Speaking of the educational situation in Vietnam nowadays, another issue that the researcher also would like to highlight here is that sexual education is not paid attention enough, even being ignored in the school and family environment. As a result, the young seriously lack knowledge about this field of sexuality. Indeed, in the traditional Vietnamese culture, the topic of sexuality is still considered "taboo", and so, is often discouraged to openly study, even discuss it, especially in the family environment (Gia Mi, 2019). In fact, according to the old way of thinking of Vietnamese people, particularly the old ones, hiding or covering is the best way to protect the young from immoral issues regarding sexuality. So, there is a popular saying among Vietnamese people that "Dung ve duong cho huou chay" [Do not draw the way for the deer to run]. Accordingly, there is a thinking that if we talk or teach the young about the issues relating to sexuality, this will stir up in them the sexual urge or desire, or at least their curiosity of knowing about it more and more, and then, in the end, they will commit the immoral acts. From my viewpoint, this way of thinking is not relevant anymore, even this is the wrong way. Indeed, in the present context where there is a "flood of information," it is better to supply the right information regarding this issue to the young, instead of hiding from them. So that, they can have the right understanding about it. If we do not provide, the youth can also know, even know better than us about it, but by their ways, and 
this will be more dangerous! So, it is better to afford them the necessary knowledge about this field as the preparation for them when they face reality.

In short, from the current context of Vietnam as presented above, we see that the main factors that can contribute to the high rate of abortion among Vietnamese teens nowadays are: the ethical values or moral lessons in life are constantly eroded and neglected in society, the lack of a comprehensive sexuality education that includes medically accurate information about abstinence and contraception for the young, and the tension between the two existing cultures in Vietnamese society today: the Western culture in which movement of "live in" is quite popular among the teenagers, and traditional Vietnamese culture in which value of traditional marriage is still highlighted, and having a baby outside marriage under any form is not accepted and welcomed. Indeed, this conflict, itself, unconsciously pushed the young girls who have unexpected pregnancies to abortion as an instant solution and remedy for them.

\subsection{Various Perspectives}

Biblical Perspective - In the Biblical time, maybe the issue of abortion did not appear yet, or at least not so popular as of now. So, there were no Biblical messages mentioned directly to this issue. However, protecting, respecting, and valuing human life is a constant concern of the Scripture from Old to New Testament.

Old Testament - In the light of the Christian faith, God created all things, including human beings. However, the only human being is created in the image and likeness of God (see. Genesis 1:26-30). Saint John Paul the Second reaffirmed this truth in another way of saying, "Human persons are willed by God; they are imprinted with God's image. Their dignity does not come from the work they do, but from the persons they are" (John Paul II, 1991, no. 11). Indeed, each human life is truly a gift from God. So, respecting and valuing our own life and the lives of others is the authentic way to thank and honor God because of this precious gift of life, and this is also the responsibility of each human being. However, as the history of salvation proved, human beings kept failing in fulfilling this responsibility. By anger and envy, Cain killed his brother, Abel (See. Gen 4: 1-16). After that, God said, "the voice of your brother's blood is crying to me from the ground" (Gen 4:10). Sadly, the human being has become the enemy of his/her fellow human being. Scripture frequently reminds us of this history of violence and considered blood as a sign of life at the same time. So, "Whoever sheds the blood of man, by man shall his blood be shed; for God made man in his image." (Gen 9:6) Besides, this God's command is constantly repeated during the Old Testament under various forms. In the book of Exodus, respecting the human life is lifted to the imperative order, the fifth commandment, "You shall not kill" (Exodus 20:13), and this commandment is the fundamental principle in valuing and protecting human life for those who believe in God at all times and all places. Following this commandment, the defenseless in society, particularly the innocent, are especially paid attention, because God loves them, protects them, and is always on their side. (See. Deuteronomy 10:17-19; Exodus 23:7). So, the deliberate murder of an innocent person is gravely contrary to God and human dignity as well. Above all, the unborn child is the most defenseless and the most innocent whom this commandment aimed to.

New Testament - In the moral issue of abortion, the core issue here is the respect and protection of human life. About this, in the New Testament, Jesus indirectly reaffirmed the validity of the fifth commandment, 'You shall not kill' when he said, "Do not think that I have come to abolish the law or the prophets; I have come not to abolish but to fulfill." (Matthew 5: 17) This means Jesus did not only satisfy with the negative dimension of this commandment, but He also wants to push this commandment to its positive dimension completely. So, in the Good News that Jesus preached to the people, He always put the life of people at the center. Indeed, he respected and valued each person, especially the voiceless, defenseless in society at that time. He publicly stated this mission when he started his journey of preaching the Good News, "The Spirit of the Lord is upon me because he has anointed me to bring good news to the poor. He has sent me to proclaim release to the captives and recovery of sight to the blind, to let the oppressed go free, to proclaim the year of the Lord's favor." (Luke 4: 18-19) Accordingly, His mission in this world is giving life, not destroy life, "I came that they may have life, and have it abundantly." (John 10:10) Indeed, his words, his actions, particularly the miracles that he performed in helping the

52 Consortia Academia Publishing (A partner of Network of Professional Researchers and Educators) 
needy are outstanding evidence about this mission of giving the life of Him.

Besides, in his Sermon on the Mount, Jesus went further very much in living this fifth commandment when he said,

You have heard that it was said to those of ancient time, 'You shall not murder; and 'whoever murders shall be liable to judgment.' But I say to you that if you are angry with a brother or sister, you will be liable to judgment; and if you insult a brother or sister, you will be liable to the council; and if you say 'you fool', you will be liable to the hell of fire. (Matthew 5: 21-22)

He also prohibited anger, hatred, and vengeance. Even, he asked his disciples to love their enemies. (See. Matthew 5: 38-48) All of these showed how much he respects and values the dignity of human persons. Indeed, for him, no reason can excuse or justify our behaviors or actions that can destroy or violate the dignity of our brothers and sisters, even our enemies.

Magisterial Perspective - From the perspective of the Catholic Church,

Human life is sacred because, from its beginning, it involves the creative action of God, and it remains forever in a special relationship with the Creator, who is its sole end. God alone is the Lord of life from its beginning until its end: no one can under any circumstance claim for himself the right directly to destroy an innocent human being. (CCC 2258)

So, the Church always says 'no' to abortion under any form, because it kills someone who cannot defend himself/herself. And so, this act of abortion directly violated the fifth commandment of God, "You shall not kill." (Exod 20:13; Deut 5:17)

In addition, in the Catechism of the Catholic Church 2270, the Church continued to affirm her stand in this issue of abortion, saying "Human life must be respected and protected absolutely from the moment of conception. From the first moment of his existence, a human being must be recognized as having the rights of a person among which is the inviolable right of every innocent being to life." Indeed,

Since the first century, the Church has affirmed the moral evil of every procured abortion. This teaching has not changed and remains unchangeable. Direct abortion, that is to say, abortion willed either as an end or a means, is gravely contrary to the moral law: You shall not kill the embryo by abortion and shall not cause the newborn to perish. (CCC 2271)

In the Second Vatican Council, the stand of the Church was also very clear about this moral issue of abortion, "God, the Lord of life, has entrusted to men the noble mission of safeguarding life, and men must carry it out in a manner worthy of themselves. Life must be protected with the utmost care from the moment of conception: abortion and infanticide are abominable crimes" (Vatican II, no. 51.3). Besides, from the standpoint of the Church, even the persons who involve directly in abortion also have to take great responsibility for that act of collaboration, "Formal cooperation in an abortion constitutes a grave offense" (CCC 2272). In addition, the Church also attached the canonical penalty of ex-communication to this crime against human life, "A person who procures a completed abortion incurs ex-communication latae sententiae" (Can. 1398). However, according to the explanation from the Church regarding this sanction, "The Church does not thereby intend to restrict the scope of mercy. Rather, she makes clear the gravity of the crime committed, the irreparable harm done to the innocent who is put to death, as well as to the parents and the whole of society." (CCC 2272)

Furthermore, the Church also explain the fundamental reasons why she stands consistently on the side of human life, saying:

The inalienable right to life of every innocent human individual is a constitutive element of civil society and its legislation: The inalienable rights of the person must be recognized and respected 
by civil society and the political authority. These human rights depend neither on single individuals nor on parents; nor do they represent a concession made by society and the state; they belong to human nature and are inherent in the person by the creative act from which the person took his origin. Among such fundamental rights, one should mention in this regard every human being's right to life and physical integrity from the moment of conception until death. (Congregation for the Doctrine of the Faith, 1987)

Besides, according to Catechism of the Catholic Church 2274, "Since it [fetus] must be treated from conception as a person, the embryo must be defended in its integrity, cared for, and healed, as far as possible, like any other human being..."

Being faithful to the Doctrine and Tradition of the Church, Pope Paul the Sixth in Humanae Vitae reaffirmed the standpoint of the Catholic Church regarding the issue of abortion, saying:

...We base our words on the first principles of a human and Christian doctrine of marriage when We are obliged once more to declare that the direct interruption of the generative process already begun and, above all, all direct abortion, even for therapeutic reasons, are to be excluded as lawful means of regulating the number of children. Similarly excluded is any action which either before, at the moment of, or after sexual intercourse, is specifically intended to prevent procreation - whether as an end or as a means. (Paul VI, 1968, no. 14)

Maintaining this stand relating to abortion, Saint John Paul the Second mentioned indirectly this issue in Evangelium Vitae when he said,

It is explicit that the precept 'You shall not kill' is strongly negative: it indicates the extreme limit which can never be exceeded. Implicitly, however, it encourages a positive attitude of absolute respect for life; it leads to the promotion of life and to progress along the way of a love that gives, receives, and serves. (John Paul II, 1995, no. 54)

In short, over time, although encountering different biological theories, the Catholic Church never changed her firm conviction that abortion is gravely wrong at every stage. Accordingly, early abortion was seen as attacking and killing a being with human destiny (The United States Conference of Catholic Bishops). Besides, given the scientific fact that human life begins at the moment of conception (the American Medical Association, 1871), the Church's opposition to abortion is understood in the light of the principle that every human life has inherent dignity, and thus, must be treated with respect due to a human person. So, with absolute respect to God's will, in any situation, the Church always advises her children to try to avoid abortion as much as possible (The United States Conference of Catholic Bishops).

Cultural Perspective - In Vietnamese culture, Vietnamese folk often believe that children are the family's precious property. So, the parents who have many children are blessed and the barren parents are unhappy. This also shows partly the respect for human life in general and the children in particular in Vietnamese culture, especially in traditional family culture. Children are the expectation of husband and wife after marriage. This is a sacred desire to preserve the lineage, deepen the love between husband and wife, and please the family from both sides, the clan, and the village. Therefore, Vietnamese folklore has a habit of asking newlyweds: "Is there good news yet?" meaning pregnant yet? Pregnancy is seen as good news by everyone, for it is a sign of the fruitfulness of the conjugal love that others wish for new couples. This is very close to the Christian concept of "the good news of life": life comes from God, life is God's gift to the couple and all humanity.

And then, when the "good news" comes, the young mothers are taught to best protect the unborn children in their wombs. They have to take care of their physical and mental health, eat nutrients, see beautiful pictures, think and act well ... so that their babies will be born healthy, beautiful, and intelligent. In addition, they also have to abstain from unhealthy foods and drinks, bad attitudes, words, and behaviors that can cause bad effects 
Abortion among teenagers in Vietnam today

on the babies later on. That is the concept of "pregnant religion", which means educating the child while he/she is still in the womb. This habit stems from the experiences and teachings of the Vietnamese ancestors (Toan Anh, 1995). And this fine cultural beauty has been passed on to the daughter or daughter-in-law by the mother or mother-in-law in the family from generation to generation. And then, when the child is born, the grandparents often guide and teach the new parents to nurture and educate the child, so that the child can grow up in the best way. Vietnamese ancient proverb often says: "Hold the child like an egg, take care of him/her like take care of flowers," to express the gentle care for the children, respect and love children as treasures of the family.

Besides, from the perspective of respecting the lives of children, the Vietnamese have a disparaging and sarcastic look at the infertile:

"Having a husband without children,

Like flowers blooming on the mountain alone."

This attitude is very close to the Biblical view in both the Old and New Testament: a woman without children is unhappy and is despised by society. Children play an important part in creating a warm and happy family where the love of the husband and wife can be truly complete, and the motherhood of a woman is actualized. Thus, children are considered, by their grandparents, to be more precious than gold. Since then, we realize that a culture of respecting fetal and infant life has been embedded in the daily life of Vietnamese people. So, aborting an unexpected pregnancy or eliminating the unborn child is considered inhumane work, and is absolutely forbidden by custom and law in the traditional culture of Vietnam.

In addition, with the conception that "Mr. Heaven gives birth to the elephants, He also will provide grass to them," and, "The children are from Mr. Heaven and He will nurture them," the birth restriction or abortion of the fetus hardly happens. Vietnamese people believe that children are the transmission of the life of parents and ancestors.

In short, the above are some highlights about the valuing of life and respect for the life of the fetus and children in the traditional culture of Vietnam. However, when society entered the period of urbanization and global integration, these values have been fading away, even being abolished for objective and subjective reasons (Quang Huyen, 2010).

\subsection{Personal Perspective}

In this part, I would like to present my perspective relating to the issue of abortion in general, and this issue in the context of Vietnam today in particular. First is my personal view of the issue of abortion, itself. Being a Catholic Christian, especially a religious sister, my responsibility is to follow the teachings of the Scripture and the Church relating to this issue of abortion: value, respect and protect human life with any price. However, the penalty of excommunication for the ones "who procures a completed abortion" according to Canon Law 1398, for me, should be reconsidered. I know that the intention of the Church in proposing this kind of punishment is to warn and prevent her children from this sinful act of abortion. This is very good. However, for the young generation in the present context, I do not think this way of punishment is still a relevant and effective way to them. Rather, the pastoral way, I think, should be considered. While the persons who commit the act of abortion are often the ones who do not care about God, religious belief, or religious life, how can they care for this kind of punishment, ex-communication? Or in other words, the sanction of ex-communication means nothing for them. Besides, I see that, in reality, many cases of abortion are not deserved to bear this kind of punishment. I mean that, in some cases, there is no choice for them, but abortion. So, in those cases, the situation that pushed the young girls or women to the act of abortion should be considered before this penalty is implemented.

Second is my personal view of the issue of abortion in today's Vietnamese context where the rate of abortion has been reaching an "alarming level." Indeed, based on my observation and experience, I see that most of the 
cases of abortion in Vietnamese teenagers are unexpected pregnancies. So, psychologically, they are not prepared for that situation. In addition, the pressure of being refused or rejected from their family, particularly from their parents also contributed greatly to the high rate of abortion among teenagers. They all know that having a baby outside the marriage under any form is not welcomed and accepted, even that is something shameful and humiliating for their family. In addition, their ongoing study that they need to accomplish also added more pressure on their shoulders. All of these elements pushed them to the decision of abortion. Abortion is the best solution for them in that situation. Therefore, we can infer that they abort not because they want, but they have to do so to secure their study, especially the reputation of their family.

Indeed, in a society where there is a conflict between two existing cultures as Vietnam: the Western culture in which movement of "live in" is quite popular among the teenagers, and the Asian culture in which values of traditional marriage is still highlighted, and having a baby outside marriage under any form is unacceptable, the young being pushed to the abortion is an inevitable thing. In addition, legalizing abortion, although indirectly, in Vietnamese society nowadays has also contributed to the high rate of abortion among Vietnamese teens today. This moral situation is becoming a big challenge for the ones who work in the field of education and religion as well.

Seeing the reality of abortion among Vietnamese teens together with possible challenges that can push them to the choice of abortion, and discerning them from the Biblical, Magisterial, and Cultural Perspectives, I, as a religious person and from the pastoral point of view, see that, some issues need to be considered here in the effort to improve this situation of abortion:

First, for the instant need in terms of dealing with the cases of unintended pregnancy already, the project of 'charitable home' in which the young girls, who accidentally got pregnant and had no place to be welcomed, should continue to be promoted. This kind of home has existed already in Vietnam, especially in the big cities where abortion is often performed. And in fact, this kind of home has effectively provided urgent help to the girls who are in urgent need. According to the sharing of Mrs. Nguyen Thi Mai, manager of a welcomed home namely, 'Father's House,' "This place accepts girls aged 14-22 years old, which means they cannot afford to be independent when having to raise children alone. Most of these girls are pupils, students, and workers. Instead of having to give up that pregnancy, 'Father's House' will welcome this innocent destiny" (Ngoc Phuc, 2018). In fact, at this 'Father's House,' the young pregnant girls will be taken care of until the day of delivery... For those who have not yet finished high school, the program will facilitate, so that they can continue to go to school after giving birth until they can generate enough income to support their children. Those who do not study will be consulted on vocational training and job creation" (Ngoc Phuc, 2018).

Indeed, with these kinds of welcomed homes, the young pregnant girls have a temporary place to live, at least during the time they are pregnant. And, of course, this help and support partly lessen the pressures that force them to the decision of abortion, even though accepting this help can require them temporarily paused their study for a while. In fact, after giving birth, they can continue their study as in the case of Nguyen Mai Tram, 17 years old, who came from Da Nang City. She arrived at 'Father's House' while her high-school study was still unfinished yet. Here, she was cared for until she gave birth and was given conditions to continue her study. She, herself shared, "I have been living here for three years. Because of being afraid of bad rumors from neighbors and stigma from society, my family let me temporarily stay in this place to continue to go to school until I can be independent and can support myself and my child" (Ngoc Phuc, 2018).

Actually, 'Father's House' is just one of the examples of the kind of 'welcomed home' in Vietnam today. In fact, as the urgent response to the situation of abortion in Vietnam now, many individuals and organizations, more often, the religious Congregations have voluntarily dedicated to this project of 'welcomed home' for the young girls who have an unexpected pregnancy. Luckily, this project has been approved and permitted by the government. I believe that in the situation of abortion nowadays, this kind of project is an effective and practical way in the effort to reduce the abortion rate among Vietnamese teenagers in this present context. Because, 
according to the Alan Guttmacher Institute, one of the most common reasons women choose abortion is because they cannot afford another child (Jessica Arons and Shira Saperstein, 2006).

Second, in dealing with this moral issue of abortion for the long run, I see that the teenagers in general, and the girl teens in particular, who are the main subjects in the issue of abortion here, need to be provided a comprehensive sexuality education that includes medically accurate information about abstinence and contraception (Jessica Arons and Shira Saperstein, 2006), particularly sexual health and consequences of abortion to the mental and physical health later on. The research results showed that the age of the first sexual intercourse among Vietnamese adolescents is increasingly early. However, their knowledge about contraception, HIV, and other sexually transmitted diseases (STDs) is still very limited - only about 20, 7\% uses contraception in sexual intercourse for the first time. According to health and population experts, a high number of adolescent pregnancies and abortion is not only a burden and a great challenge for the population and development of the country, but also more remarkably, it can cause serious consequences for the young generation, the future owners of the country (Nguyen Manh Kha, 2015). Therefore, education about this sexual field to Vietnamese teens is obligatory and necessary. Together with this, the teenagers' parents also need to be educated about this field, so that they can accompany and guide their children effectively.

\section{Conclusion}

In a society where abortion is becoming easily accessible and more convenient as Vietnam, plus decreasing consciousness about the value of human life, increasing the abortion rate, particularly among teenagers, is inevitable and understandable. Indeed, an "alarming" number of cases of abortion among teens as recorded in recent times is raising a big challenge for the parents and educators, particularly religious educators. Improving the situation concerning this issue of abortion is the task and responsibility of the whole society in general, and the close collaboration between the school and family, between teachers and parents in particular. First and foremost, in a context where social media and multi-accesses to different sources of information is blossoming as in Vietnam nowadays, providing comprehensive sexual education under different forms to both teenagers and their parents is a fundamental and essential step in this endeavor. Besides, creating places where young girls with unintended pregnancies can feel safe and secure for themselves and their unborn babies is also an effective and practical solution in the effort to lower the abortion rate among teenagers. In reality, this kind of project has existed and has been also supported and promoted by many individuals and organizations, especially the religious male and female congregations. And this is a good sign for a better situation relating to this moral issue of abortion among teenagers in the context of Vietnam today.

\section{References}

Arons, J., \& Saperstein, S. (2006, January 20). The right way to reduce abortion. Retrieved from https://www.americanprogress.org/issues/women/news/2006/01/20/1796/the-right-way-to-reduce-aborti on/

Ashwill, M. A., \& Thai Ngoc Diep. (2005). Vietnam today: A guide to a nation at a crossroads. London: Intercultural Press.

Catechism of the Catholic Church. Retrieved from https://www.vatican.va/archive/ccc_css/archive/catechism/ccc_toc.htm

Collins Dictionary. Retrieved from https://www.collinsdictionary.com/dictionary/english/materialism

Congregation for the Doctrine of the Faith. (1974, November 18). Declaration on procured abortion. Retrieved from https://www.vatican.va/roman_curia/congregations/cfaith/documents/rc_con_cfaith_doc_19741118_dec laration-abortion_en.html

Congregation for the Doctrine of the Faith. (1987, February 22). Instruction on respect for human life in its origin and on the dignity of procreation Donum Vitae. Retrieved from https://www.vatican.va/roman_curia/congregations/cfaith/documents/rc_con_cfaith_doc_19870222_res 
pect-for-human-life_en.html

Connery, J. R. (1977). Abortion: The development of the Roman Catholic perspective. Chicago: Loyola University Press.

Fernando, P. M. (2010). See, judge and act: Method for academic research. Quezon City: ICLA Publications.

Gao, S. (2000). Economic globalization: Trends, risks and risk prevention. Economic \& Social affairs. Retrieved from https://www.un.org/en/development/desa/policy/cdp/cdp_background_papers/bp2000_1.pdf

Gia Mi. (2019, June 8). Draw a path for the deer to run right is better than letting children figure it out on their own [Ve duong cho huou chay dung con hon de tre tu may mo]. Retrieved from https://tphcm.chinhphu.vn/\%E2\%80\%9Cve-duong-cho-huou-chay-dung\%E2\%80\%9D-con-hon-de-tre-t $\underline{\mathrm{u}-\mathrm{may}-\mathrm{mo}}$

Grisez, G. (1970). Abortion: The myths, the realities, and the arguments. Washington D.C: Corpus Books.

Ha Noi Economic University. (2015). Study of the effects of materialism and shopping preference on the behavior of Ha Noi students [Nghien cuu tac dong cua chu nghia vat chat va khuynh huong thich mua sam den hanh vi mua sam ngau hung cua sinh vien Ha Noi]. Retrieved from

https://text.123doc.net/document/3371797-nghien-cu-u-tac-dong-cua-chu-nghia-vat-chat-va-khuynh-hu ong-thich-mua-sam-den-hanh-vi-mua-sam-ngau-hung-cua-sinh-vien-ha-no-i.htm

Hoang Lam. (2019, July 3). Vietnamese digital marketing report of 2019 [Bao cao thi truong dien tu o Viet Nam nam 2019]. Retrieved from https://andrews.edu.vn/bao-cao-digital-marketing-viet-nam-2019/

John Paul II. (1991, May 1). Encyclical letter Centesimus Annus. Retrieved from http://www.vatican.va/content/john-paul-ii/en/encyclicals/documents/hf_jp-ii_enc_01051991_centesim us-annus.html

John Paul II. (1995, March 25). Encyclical letter Evangelium Vitae. Retrieved from http://www.vatican.va/content/john-paul-ii/en/encyclicals/documents/hf_jp-ii_enc_25031995_evangeliu m-vitae.html

Lan Anh. (2018, November 19). 32 years of innovation, Vietnam is in the top 50 of world economies [32 nam doi moi, Viet Nam lot top 50 nen kinh te the gioi]. Retrieved from https://www.brandsvietnam.com/17031-32-nam-doi-moi-Viet-Nam-lot-Top-50-nen-kinh-te-the-gioi

Lespinay, G. (2009). Vocations and their formation today. New York: Paulist Press.

Minh Chau. (2019, September 4). Alert status of adolescent abortion [Bao dong tinh trang nao pha thai tuoi vi thanh nien]. Retrieved from https://baodansinh.vn/bao-dong-tinh-trang-nao-pha-thai-tuoi-vi-thanh-nien-20190904150523754.htm

Nguyen Manh Kha. (2015). Abortion: A moral and social issue [Pha thai: Mot van nan luan ly va xa hoi]. Retrieved from http://www.simonhoadalat.com/giaoducgd/giaoduc/phathai2.htm

Nguyen Thang. (2019, March 13). What is media? Their pros and cons [Phuong tien truyen thong la gi? Nhung uu va nhuoc diem cua chung]. Retrieved from https://marketingai.admicro.vn/phuong-tien-truyen-thong-la-gi/

Nguyen The Long. (2012). Family: Traditional values [Gia dinh: Nhung gia tri truyen thong]. Ho Chi Minh: Van Hoa- Thong Tin Publications.

Nguyen Van Dan. (2009). Vietnamese people and culture in the renewal and integration era [Con nuoi va van hoa Viet Nam trong thoi ky doi moi va hoi nhap]. Ha Noi: Khoa Hoc Publications.

Paul VI. (1968, July 25). Encyclical letter Humanae Vitae. Retrieved from http://www.vatican.va/content/paul-vi/en/encyclicals/documents/hf_p-vi_enc_25071968_humanae-vitae $\underline{. h t m l}$

Pham Xuan Nam. (2000). Overview of Vietnamese society during the renewal process for development and international integration [Tong quan ve xa hoi Viet Nam trong qua trinh doi moi de phat trien]. Retrieved from http://www.hids.hochiminhcity.gov.vn

Quang Huyen. (2010, May 26). The conception of the life of the unborn child in Vietnamese culture [Quan niem ve su song cua thai nhi trong van hoa Viet Nam], posted by Katty Nguyen. Retrieved from http://baovesusong-chongphathai.blogspot.com/2010/05/quan-niem-ve-su-song-cua-thai-nhi-trong.html

Thai Ba Dung. (2019, May 20). Vietnam's economic growth is among the highest in the world [Toc do tang truong

58 Consortia Academia Publishing (A partner of Network of Professional Researchers and Educators) 
kinh te Viet Nam thuoc nhom cao nhat the gioi]. Retrieved from https://tuoitre.vn/toc-do-tang-truong-kinh-te-cua-viet-nam-thuoc-nhom-cao-nhat-the-gioi-20190520100 401026.htm

The Code of Canon Law. (2014). Pasay City: Paulines Publishing House.

The United States Conference of Catholic Bishops. Life and dignity of the human person. Retrieved from https://www.usccb.org/beliefs-and-teachings/what-we-believe/catholic-social-teaching/life-and-dignityof-the-human-person

The United States Conference of Catholic Bishops. Respect for unborn human life: The Church's constant teaching. Retrieved from https://www.usccb.org/issues-and-action/human-life-and-dignity/abortion/respect-for-unborn-human-lif e-

Toan Anh. (1995). Old tradition: Vietnamese people and tradional habits [Nep cu: Con nguoi Viet Nam, phong tuc co truyen]. Ha Noi: Van Hoa Publications.

Tuong Cu. (2017). Protecting the unborn child [Bao ve thai nhi]. Retrieved from https://www.catholic.org.tw/vntaiwan/thainhi/thainhi04.htm

Van Yen. (2019, May 15). Interviewing father Thomas Vu Quang Trung [Phong van cha Toma Vu Quang Trung]. Retrieved from https://www.vaticannews.va/vi/church/news/2019-05/phong-van-cha-toma-vu-quang-trung-ve-uy-ban-t u-si-thuoc-hdgmvn.html

Vatican II. (1965, December 7). Pastoral constitution on the Church in the modern world. Gaudium et Spes. Retrieved from https://www.vatican.va/archive/hist_councils/ii_vatican_council/documents/vat-ii_const_19651207_gau dium-et-spes_en.html

Vov, Vn. (2020, January 5). Innovation of the year of 1986: Lessons from the communist party's thought innovation [Doi moi nam 1986: Bai hoc tu doi moi tu duy cua dang]. Retrieved from http://kinhtedothi.vn/doi-moi-nam-1986-bai-hoc-tu-doi-moi-tu-duy-cua-dang-361798.html 
Dinh, K. A. T.

60 Consortia Academia Publishing (A partner of Network of Professional Researchers and Educators) 